\section{THE PRODUCTION AND CONCENTRATION OF A SERUM FOR ROCKY MOUN- TAIN SPOTTED FEVER}

\section{PRELIMINARY NOTE * \\ P. G. HEINIEMANN AND JOSIAH J. MOORE CIIICAgo}

Ricketts and Gomez ${ }^{1}$ lave demonstrated that the horse is susceptible to inoculation with spotted fever virus, and that after recovery the serum has protective properties similar to the blood of guinea-pigs which have recovered from the disease. T'wo years ago one of us, associated with Ricketts, succeeded in obtaining from a loorse a large amount of serum, which was used to a limited extent in the Bitterroot Valley. Owing to the small number of cases on which it was used, the results have so far thrown no light on its efficacy.

At the request of the counties of Ravalli and Missoula in western Montana, the necessary funds having been furnished by these counties, we proceeded to inoculate two horses with 200 c.c. of spotted fever virus each. The virus was divided into two parts in each case, one part being inoculated into the jugular vein, the other part subcutaneously back of the shoulder. This proceeding was adopted, because it is still undetermined which method is the -more effective one. Three weeks after the first inoculation, Horse 1 was given another inoculation of 460 c.c. virus, the method of injection being both intravenous and subcutancous as before.

The first injections produced a fever in both horses. Iorse 1 had a temperature of $103.5 \mathrm{~F}$. on the fourth day after inoculation. Blood was taken on each of five days, while the temperature was above normal, and each lot inoculated into two guinea-pigs. The blood taken on the fourth day, when the temperature had reached the maximum, was infective for guinea-pigs, and was transferred several times from the first guinea-pig, to prove that the infection really was spotted fever. The blood taken on the other four days proved non-infectious. This fact possibly bears out the statement of Ricketts that the concentration of the virus varies greatly in different susceptible animals. We interpret the results as indieating that the concentration of the virus in the horse is very low, and a sufficient amount of infectious material was contained in the blond of the horse only on the day of the highest fever.

Horse 2 showed a temperature curve similar to that of Horse 1. The maximum was reached on the fifth day (103.4 F.). We drew blood from this horse on four dny's of the fever, but missed drawing blond on the day of the highest temperature. The guinen-pig inoculations from the blood proved negative.

The protective value of the serums from both horses was tested by injecting guinea-pigs of an approximate weight of $250 \mathrm{gm}$. with 1 c.c. of virus and varying amounts of the serum, diluted with sufficient physiologic salt solution to make the volume of the serum injected uniformly 3 c.c., excepting when 5 c.e. of serum were given. The virus and the serum were injected separately into the perituneal cavity, and not mixed before injection. We believe that this makes a more rigid test than if the serum and virts were mixed before injection. eliminating a possible restraining effect of the serum on the live virus. No preservative was added to the serums in these experiments.

- From the Serum Divikion of the Memorial Institute for Infec. tlous Disenses, Chlcrgo.

1. IRicketts and Gomez: Jomr. Infect. Dis., 1008, v, 221.
Without giving the results in detail, we found that the serum had no protective value, even in as large a dose as 5 c.c. of undiluted serum, if the serum was drawn earlier than seven to eight days after the temperature of the horse was normal, Tests with a serum drawn from Horse 1 eight days after the temperature had become normal, protected guinea-pigs only if 5 c.e. of serum were injected with 1 c.c. of virus. Serum from Horse 2 , drawn ten days after normal temperature had become constant, protected guinea-pigs, if 1 c.c. was given.

After Horse 1 had received the second injection of virus, there was no temperature reaction, excepting that within two hours after the injection, there was a temporary rise of two degrees, accompanied by profuse perspiration, possibly due to slock or an anaphylactic reaction. The potency of the serum drawn twelve days alter inoculation had increased, so that 0.5 c.c. of serum gave complete protection against 1 c.c. of virus. Partial protection was evident in doses as small as 0.125 c.c., the fever appearing on the ninth, tenth or eleventh day.

Sucessful attempts have been made in concentrating the serum of Horse 1 after the second injection, and of Horse 2 after the first injection. The method of concentration is similar to the one in general use in the concentration of diphtheria antitoxin. The greater part of the antibodies is evidently connected with the pseudoglobulin fraction, as in diphtheria antitoxin. 'The concentrated serums protected in the following amounts:

Serum I B, .01 c.c. protected against I c.c. virus

Serum 2, ,05 c.c. protected against l c.c. virus

Preliminary experiments on the value of immune horse-serum as a curative agent are encouraging and will be continued in the near future.

1405 East Fifty-Seventh Street.

\section{THE PROPHYIAXIS AND TREATMENT OF SUMMER DIARIRIEA}

ALFRED F. HESS, M.D. NEW YORK

There is hardly any subject in pediatries about which more has been written than the one whlich I am to treat in this paper. 'This disease, or group of diseases, has suddenly come to be considered of national importance, to be compared in its ravages only with tuberculosis, and worthy of the full attention of national boards of health and of cconomists. It is, therefore, very clear that, in the short space of this paper, there can be no thought of covering the treatment of a disease of this magnitude, and that I must confine myself rather to a broad consideration of the principles involved. It would also seem that at the present time the subject is in such a chaotic state-for we can find authority for almost every conceivable method of feeding - that it would be untimely and to little purpose to go beyond the consideration of general principles into the realm of detail.

In the prophylactic treatment of summer diarrhea the greatest stress has been laid on the importance of nursing, and rightly so, as the statistics of all lands are in accord that, however we may explain the fact, the nursing baby is best safeguarded against gastro-intestinal disturbances. 'This, then, is the corner-stone of prophylaxis. For the infant depending on cow's milk for nourishment, however, and thereby gravely exposed to danger, we have concentrated our efforts in making a safe food available. This work includes the inspection of farms, of the milk in transit and in the stores, in requirements 